\title{
Corporate governance research on the free web: a selected annotated guide
}

\author{
Sophie Bury
}

\author{
Richard Leblanc
}

\begin{abstract}
Purpose - The web offers a large and ever expanding range of information sources on the popular and widely researched topic of corporate governance. This paper aims to introduce keys sites of quality and relevance to those interested in researching the field of corporate governance using freely available web resources. It will also aims to prove useful to librarians who wish to develop web-based subject pathfinders in this field or who want simply to connect with and build their knowledge of major topics and participants in the field of corporate governance.

Design/methodology/approach - By way of introduction important or groundbreaking works in the corporate governance literature are identified and cited in the paper to place selected web sites within the context of recent and historic developments in the area of corporate governance. $A$ wide range of web-based sources were consulted and critically evaluated in the study.

Findings - The result of this work is a significant sampling of quality web-based information sources with evaluative annotations.

Originality/value - Given the recent explosion in information resources available on the topic of corporate governance, this paper will prove especially timely and useful to anyone interested in accessing and interacting with quality information on the free web from a wide range of significant players and stakeholders in the corporate governance arena.
\end{abstract}

Keywords Corporate governance, Worldwide web, Internet, Information retrieval, Classification

\section{Introduction}

Corporate governance has, in more recent years, become one of the most commonly used terms in the modern corporation. The empirical research and literature has burgeoned and the field is highly interdisciplinary.

Stakeholders in the corporate governance arena are many and wide-ranging and their participation in this field has spawned a rich and varied range of information resources pertaining to distinct disciplinary fields and practitioner interests. The corporate governance researcher thus needs to have an in-depth understanding of the 
diverse roles various stakeholders play and how they "fit" together in the complex arena of corporate governance as it exists today.

Corporate governance has come to underpin systematically the work of many business academics and practitioners alike, and their information and research needs present challenges not only for them, but also for the information professionals who assist them.

\section{The challenges of corporate governance research}

The information, reference and research needs of corporate governance scholars today may be divided into two broad groupings: quantitative and qualitative. For quantitative research (the majority of statistical research currently being conducted in the corporate governance field, broadly defined), these scholars require efficient and effective access to publicly disclosed quantitative information, e.g. corporate financial performance and executive compensation figures, from companies directly and third party databases. This data is typically accessed, synthesized, analyzed and manipulated to address research questions, which involve explaining and predicting certain relationships amongst variables through rigorous quantitative parametric tests.

Qualitative corporate governance researchers desire access to a myriad of verbal sources and reports, including government rules and guidelines and, in particular, corporate governance polices, procedures and practices that boards, committees and management have adopted in order to comply with government rules and guidelines to which they are now subject. A challenge here, for the qualitative researcher, is that what is most valuable is data that is least publicly available, that is, e.g. the understanding of dynamics and interactions of boards in session, how boards function within the boardroom, boards-management relations, the effectiveness of the board and the competencies, skills and effectiveness of individual directors themselves, including issues of board leadership and the qualities and behaviors of the chair of the board.

For both groups of governance researchers, however, a central challenge is to obtain the most relevant and current data, given the sheer pace of change, information needs, and the emergence of wide-ranging and multi-faceted information resources.

The purposes of this article are to: distil and evaluate critically the most important and robust web sites offering significant freely available information content; provide value to the corporate governance researcher and information professional alike; and offer a solid foundation for embarking on corporate governance research on the free web.

\section{Corporate governance - definition and historical perspective}

There is no single commonly accepted definition of corporate governance. Moreover, the definition may vary in different contexts or different countries (Solomon and Solomon, 2004). In very simple terms, corporate governance refers to how a corporation is governed (National Association of Corporate Directors, 2006). Laws, regulations or formal policy play a significant role in determining this, of course. For example, legally, a board of directors is vested with the authority to manage or supervise the management of the business and affairs of a corporation. Each director and officer, in exercising their powers and discharging their duties, is required by law to: act honestly 
and in good faith with a view to the best interests of the company (otherwise known as the director's "fiduciary duty"); and exercise the care, diligence and skill that a reasonably prudent person would exercise in comparable circumstances (otherwise known as the director's "duty of care"). While these duties are deliberately broad in their scope, what has occurred in the last several years is that specific duties and responsibilities have been imposed on, and expected of, directors, by regulations, shareholder guidelines and otherwise, in a broad variety of areas (e.g., board structure and composition, director qualifications and financial, risk and compensation oversight by the board) in order to ensure that boards of directors adequately oversee the management of the organization and act in the best interests of the company and all of its shareholders at all times.

Historically, definitions of corporate governance also took into consideration the relationship between the shareholder and the company, as per "agency theory", i.e. director-agents acting on behalf of shareholder-principles in overseeing self-serving behaviors of management. However, broader definitions of corporate governance are now attracting greater attention (Solomon and Solomon, 2004). Indeed, effective corporate governance is currently understood as involving a wide number of participants. The primary participants are management, shareholders and the boards of directors, but other key players whose interests are affected by the corporation are employees, suppliers, customers, partners and the general community. Therefore, corporate governance, understood in these broadening social contexts, ensures that the board of directors is accountable not only to shareholders but also to non-shareholder stakeholders, including those who have a vested interest in seeing that the corporation is well governed. Some corporate governance scholars (Carter and Lorsch, 2004; Leblanc and Gillies, 2005) also argue that at the heart of good corporate governance is not board structure (which receives a lot of attention in the current regulations), but instead board process (especially consideration of how board members work together as a group and the competencies and behaviors both at the board level and the level of individual directors). As a result, the current scholarly discourse about the nature of corporate governance has come to reflect this body of research.

Historically, corporate governance and boards of directors received relatively little attention, e.g. management teaching and research and popular writing. The term "corporate governance" was not even used until well in to the 1980s. However, even before the major corporate meltdowns of the early part of this century which received extensive media attention - Enron, Worldcom, Adelphia, to name but a few corporate governance and boards began to receive more attention than before. Factors such as the unfriendly takeovers movement, the increasing importance of institutional investors, heightened attention to directors' legal liability, and pressure for more efficient and effective corporations in a increasingly open, fast-paced and technologically advanced business world, meant that beginning in the 1980 s and continuing and growing within the 1990s, corporate governance received increasing attention among practitioners, academics and other groups (Leblanc and Gillies, 2005). As a result of the major corporate scandals of 2001-2003, much corporate fraud came to light and issues such as excessive executive compensation and accounting and auditing malpractice came under the microscope. In response to these scandals in the USA and elsewhere, companies have had to ensure closer scrutiny and oversight of their activities (Carter and Lorsch, 2004). Proposals for reform have come from many 
directions, in many different forms, but an immediate response in many countries has been to enforce tighter regulations, codes, or principles and/or to enact specific legislation, e.g. the Sarbanes-Oxley Act (2002) in the USA.

\section{Development of corporate governance on the free web}

The fact that corporate governance has developed in to a robust and information-rich field of interest to researchers and practitioners alike, should come as no surprise, when one considers the sheer scope of this field, in all of its manifestations, e.g. risk management, executive compensation, financial integrity and the nomination and qualifications of directors. Information pertaining to corporate governance comes in many shapes and forms, and the free web is no exception. Indeed, here one finds a plethora of information emanating from a wide range of stakeholders with vested interests in participating in the engagement on corporate governance. This stakeholder participation and dialogue has spawned a rich and varied number of information resources from academics, shareholders (especially institutional shareholders), directors, corporate secretaries, regulatory bodies, stock exchanges, legal, accounting and consulting firms, research centers and institutes, corporate watchdogs, international government agencies and accounting and auditing bodies. As a consequence, information on numerous dimensions of corporate governance, from the frame of reference of many diverse roles and perspectives, is available on the free web. Several of these sites have in common the goal of promoting enhanced corporate governance principles, policies and practices.

\section{Selection of corporate governance web sites}

A central goal in writing this article is to be selective and to highlight some of most significant sites for corporate governance research on the free web - those which either themselves offer information of use to those interested in researching corporate governance or act as gateways to helpful resources.

Quality was clearly an important consideration in choosing web sites for this article, and relevance, authority, currency and comprehensiveness of information available on the web site were considered in making selections. The authors paid close attention to the authority and credibility of each site by considering closely the reputation, credentials and organizational affiliation of site authors. The purpose and intended audience(s) were also considered when selecting sites to include. It should be remembered that, in essence, there is no such thing as an entirely "objective" web site on corporate governance - the nature of information found on any site will inevitably be influenced by the specific agenda, goals, mission, etc., of the authoring body. Nor is it, indeed, desirable to isolate sites that are largely "impartial" or "objective", as corporate governance is a field influenced by the activities and perspectives of a wide range of stakeholders. It is therefore important to understand their varied contributions and viewpoints to ensure one acquires, or at least is exposed to, a broad perspective on what is a very multi- and interdisciplinary field that is rich with debate and dialogue. As such, this article aims to ensure the reader is provided with a succinct and accurate introduction to valuable, free web-based information sources from a representative cross-section of credible and reliable names and authors in the field.

The emphasis is on sites that assist users to learn about important corporate governance definitions, codes, regulations, and legislation, as well as current 
principles, issues and practices in corporate governance. In some cases, the web sites of major organizations have not been included because they are not in themselves intended to disseminate knowledge or because they include information that is predominantly fee-based.

The first portion of this article, sections 1-4, aims to outline keys sites for corporate governance definitions, codes, principles, rankings/ratings, as well as identifying key sites for retrieval of corporate filings, which often serve as an important source of corporate governance information. The latter portion of the article, sections 5-8, highlights web sites from significant participants or stakeholders in corporate governance, including professional associations, research centers, institutes and think-tanks, corporate "watchdogs", advocacy groups and institutional investors. In terms of the organization of sites within each section to follow, alphabetical listing by name applies, except in two cases. First, where geographic designation of the sites, was considered most important, e.g. in the case of corporate governance guidelines, codes and legislation, sites are listed by geographic designation first (with priority given to North American site listings), followed by an alphabetical listing within sections. Second, in the section covering research centers, institutes and think tanks, sites are divided into an academic and independent category, and within each of these sub groupings an alphabetical listing by name is then applied.

\section{Corporate governance glossaries/definitions on the web}

Below is a recommended list of corporate governance glossaries or definitions that are freely available on the web.

\subsection{Corporate Governance Defined (http://corpgov.net/library/definitions.html)}

This is a resource offered by CorpGov.Net, which acts as a portal site to many corporate governance resources worldwide, as well as offering a number of useful information resources that it hosts on its own site. This resource will prove valuable for those who are just beginning to familiarize themselves with the field of corporate governance because it provides a large number of definitions of corporate governance from leading scholars, professional associations and other well-known organizations in the field.

\subsection{Corporate Governance Glossary (www.corp-gov.org/glossary.php3)}

This site contains an extensive glossary of corporate governance terms that is hosted on the web site of the OECD/World Bank - Russian Corporate Governance Roundtable. It was compiled using materials from Institutional Investor Services, or "ISS," a leading name in the field of corporate governance.

\section{3 Investor Responsibility Research Center (IRRC): Glossary of Industry Terms (www.} irrc.org/resources/glossary.htm)

IRRC, a long-established and well-regarded organization, conducts research on corporate governance and social responsibility. IRRC's glossary provides definitions of terms used in the investment world, but also includes many definitions of concepts integral to the field of corporate governance. 


\section{Corporate governance guidelines, codes and legislation}

As stated already, there has been widespread adoption in recent years of new codes, regulations and legislation designed to improve corporate governance. The more recent reforms have been enforced in large part as a reaction to shareholder and public concern in the wake of large-scale corporate governance failure in the form of massive corporate fraud and scandal as evidenced most famously in the case of Enron. However, it should be noted that even prior to this time some, significant progress had been made in terms of corporate governance codes and principles in the case of several countries. The UK, for example, was one of the pioneers in this area (National Association of Corporate Directors, 2006) and in 1992, the Committee on the Financial Aspects of Corporate Governance, chaired by Sir Adrian Cadbury, issued the Code of Best Practice for Corporate Governance (often referred to as The Cadbury Report). The London Stock Exchange then required all listed companies to disclose whether or not they conformed to the code. The Cadbury Report had an important role in inspiring the introduction of national guidelines or codes in other countries.

Today, many countries with developed economies have adopted corporate governance codes (National Association of Corporate Directors, 2006). Typically such codes or principles set forth rules in a regulatory context and are enacted into law as in the case of the Sarbanes Oxley Act of 2002 or are made a condition for a company to be registered on a major exchange. Indeed many of the reports that have outlined new codes or principles have been launched under the auspices of a major stock exchange, e.g. the Combined Code by the London Stock Exchange (LSE) or the Dey Report in Canada by the Toronto Stock Exchange (TSE). While codes exist largely at a national level, some international agencies, such as the OECD, have adopted corporate governance principles that are designed to apply more broadly.

While some information is fee-based, it is possible to use the free web to find an impressive wealth of information pertaining to corporate governance guidelines, codes and legislation. Some major sites for this kind of information are highlighted below. Note emphasis has been given to North American sources of information.

\subsection{Canada}

2.1.1. Index of Canadian Corporate Governance Codes (ECGI) (www.ecgi.org/codes/ search_code.php?'country $=$ Canada). The European Corporate Governance Institute (ECGI) provides access to the full-text of major Canadian corporate governance codes which have been adopted since The Dey Report (1994).

2.1.2. National Policy 58-201 Corporate Governance Guidelines (www.osc.gov.on.ca/ Regulation/Rulemaking/Current/Part5/rule_20041029_58-201_corp-gov-guidelines. jsp) and National Instrument 58-101 Disclosure of Corporate Governance Practices (www.osc.gov.on.ca/Regulation/Rulemaking/Current/Part5/rule_20041029_58-101_ disc-corp-gov-prac.jsp). The Canadian Securities Administrators' (CSA's) National Policy 58-201 Corporate Governance Guidelines and the related National Instrument 58-101 Disclosure of Corporate Governance Practices has been in force in Canadian jurisdictions since 30 June 2005.

2.2. USA

2.2.1. Index of US Corporate Governance Codes (ECGI) (www.ecgi.org/codes/all_codes. $p h p \# U S A)$. This web site includes a listing from the ECGI with links to full-text 
documents of the major corporate governance codes and national policy documents in the USA, including stock exchanges (NYSE), institutional shareholders (TIAA-REF and CalPERS) and other major organizations such as the Business Roundtable and the National Association of Corporate Directors (NACD).

2.2.2. Final NYSE Corporate Governance Rules 2003 (www.ecgi.org/codes/ documents/finalcorpgovrules.pdf). This site includes the full-text of these rules approved by the SEC on November 4, 2003.

2.2.3. Sarbanes-Oxley Act 2002 (www.sec.gov/about/laws.shtml\#sox2002). The Sarbanes-Oxley Act or "SOX," as it is commonly known, was introduced by the Bush administration in the wake of Enron and other corporate scandals in the USA. The Act includes legislation designed to prevent and combat corporate and accounting fraud, mandates external auditor independence, emphasizes heightened compliance and disclosure by US corporations and enhances corporate accountability. The full-text of the Act is available on the web site of the Securities Exchange Commission as well as links to all Commission rulemaking and reports issued under the Act.

\subsection{International}

2.3.1. Index of Corporate Governance Codes \& Principles (ECGI) (www.ecgi.org/codes/ all_codes.php). This web site includes a browsable (alphabetically by country) and searchable listing of the full-text of corporate governance codes and principles from some 60 countries worldwide. Access to the full-text of these documents is provided in each case.

2.3.2. World Bank - Corporate Governance: Observance of Standards and Codes (http://rru.worldbank.org/GovernanceReports/). The World Bank oversees the assessment of the application of the OECD Principles of Corporate Governance within many countries worldwide. Results of these assessments are published within the Reports on the Observance of Standards and Codes (ROSC). These reports can be downloaded for free on the above web site and offer reviews of each assessed country's legal and regulatory framework, corporate governance practices and compliance of each country's listed firms, and the legal and regulatory framework relative to an internationally accepted benchmark. This site also offers access to the corporate governance assessment template and the full-text of the OECD Principles of Corporate Governance.

\section{Corporate disclosure filings}

In many jurisdictions, public companies are obliged by law to file with national or regional securities regulators to ensure investors and the public at large have access to information about the business and affairs of public companies. This plays an important role in promoting and ensuring accountability and transparency. Filings from publicly traded companies can be a very useful source of information for individuals engaged in corporate governance research. Indeed, proxy research is a major field in corporate governance. While many firms pay organizations such as Institutional Shareholder Services (ISS) and the Investor Responsibility Research Center (IRRC) to conduct this research on their behalf, it is also possible to retrieve proxy filings on the free web and engage in one's own research. It should be noted, however, that the freely available services typically offer less functionality than fee-based services, e.g. LIVEDGAR, a source for US filings. 
Corporate governance researchers use proxy circulars (known as the $14 \mathrm{~A}$ form in the USA) as an important source of information on companies' boards of directors and corporate governance practices. These circulars include such information as the number of directors on a board, their names, biographical information, employment history, compensation and stock option details, as well as information about other boards on which they sit, and about the number of independent directors on the board. Proxy circulars also include information on board committees, e.g. audit committees, compensation committees and nomination/governance committees.

In addition to proxy circulars, other filings may prove useful in researching corporate governance. For example, the $10 \mathrm{~K}$ form or the annual report to shareholders will be very useful for those interested in what a company is reporting about its own corporate governance practices and principles. Note that while the main body of the annual report should be consulted, the footnotes to the financial statements should also be reviewed, as they quite often contain more information on executive compensation, e.g. bonuses and stock options, than is available in the main body of the report.

The focus of the recommended sites outlined below is on North American sources.

\subsection{Canada}

3.1.1. SEDAR (www.sedar.com). SEDAR is the System for Electronic Document Analysis and Retrieval. This is the official site of the Canadian Securities Administrators (CSA), providing access to the full-text of Canadian public securities filings from 1997 onward. This site supports searching by public company or by investment fund names. Industry group and document type may also be specified as well as date limits. Full-text searching of filings is not supported.

\subsection{USA}

3.2.1 EDGAR (www.sec.gov). This is the US Securities and Exchange Commission's (SEC's) database of public filings for US publicly-traded companies. Filings for most companies are available back to the mid 1990s. Note that full-text searching of filings (last four years only) has recently been introduced constituting a very valuable enhancement to this resource.

3.2.2. EdgarScan (http://edgarscan.pwcglobal.com/recruit/other.html). This is an interface to EDGAR provided by PriceWaterhouseCooper. In simple search mode, filings may be searched by company name or ticker symbol. A recent and new advanced search feature offers full-text searching of documents, which is significant, as researchers of corporate governance matters, will quite often wish to track terms in the full-text of filings.

\subsection{International}

3.3.1. Company Annual Reports Online (CAROL) (www.carolworld.com/). CAROL Ltd, a UK-based organization, provides access to the annual reports of many major corporations around the world. Access is free, though registration is required.

\section{Corporate governance rankings/ratings}

Investors, especially institutional investors, pay for services to assist them in assessing the quality of governance in firms in which they invest. Institutional Shareholders Services (ISS), GlobalMetrics International (GMI), Standard \& Poor's, Moody's Investor 
Services and Fitch Ratings are just some of the major firms that have developed methods for measuring and assessing corporate governance (National Association of Corporate Directors, 2006).

Ratings are generated by weighing various factors that may be linked to corporate governance effectiveness, e.g. the number of independent directors on a board, the separation of the CEO and chair, the number of boards on which directors serve, etc. The scores or rating of firms assessed by these rating organizations are then used by investors to gauge the effectiveness of governance and may also inform recommendations on how governance might be changed or enhanced within a specific corporation where investments are held. Such ratings are not without academic criticism however, e.g. Jeffrey Sonnenfeld has been vocal that some of the emphasis of rating agencies is based on "myths" (Sonnenfeld, 2004; Leblanc and Gillies, 2005).

As the goal of this article is to highlight freely available web resources for corporate governance research, the web sites of the various ratings agencies named above are not recommended as a key source of information. While visiting these sites will provide the user with information about how ratings are compiled, and in some cases offer a sample ratings report, ratings for individual companies are clearly fee-based.

However, not insignificantly, some of this ratings information is now available in the public domain thanks to a number of recent developments documented in a Wall Street Journal article (Kim, 2005).

\subsection{Yahoo! Finance - ISS Corporate Governance Quotient (CGQ) now freely available (http://finance.yahoo.com)}

ISS corporate governance ratings covering some 7,500 companies were previously available only to clients. Now the "top-level" scores are available for free on Yahoo! Finance. This score rates the company's performance against a broader index or sector. The ratings of each company are based on consideration of 61 variables, including the composition of the board, compensation of executives, integrity and independence of the audit process and the assessment of the effectiveness of the board. In order to find the CGQ for an individual company, one looks up the company by ticker symbol and then clicks on the link to "Company Profile". A category named corporate governance is made available and information is provided about the CGQ of the company relative to other S\&P 500 companies as well as to other companies operating in the same industry sector.

\section{Professional associations}

Selected web sites of leading and influential corporate governance professional associations and societies have been included in this article as they represent professionals and members in the field of corporate governance, e.g. CEOs, directors, and corporate secretaries. As such, these web sites often include authoritative and expert information, reports, and other documentation pertaining to the field of corporate governance. Professionals are additionally often very much on the pulse of current issues and concerns in this field through their working lives on a day-to-day basis, and their web sites thus play a significant role in making sure the corporate governance researcher keeps him/herself in touch with currently relevant corporate governance issues in the practitioner world. 


\subsection{Canada}

5.1.1. Institute of Corporate Directors (ICD) (www.icd.ca)). This member organization represents the director community in Canada. Membership benefits include peer networking, continuing education opportunities for directors, access to research and other information sources on corporate governance and more. While much of the information and services made available on the web site is fee based, there are some valuable freely available sources, primarily within the section titled "Library". This includes some publications of the Institute, in addition to information about the Canadian Securities Administrators (CSA's) Proposed Governance Guidelines, and a section titled "Resources and Links" which includes results of corporate governance surveys conducted by ICD in partnership with others, as well as recommended internet resources for corporate governance.

\subsection{USA}

5.2.1. The Business Roundtable (www.businessroundtable.org/). This is an association of chief executive officers from leading US companies. This organization advocates for public policies designed to boost economic growth and stimulate a dynamic economy and a well-trained US labor force. Its members work on ten major task forces which focus on issues designed to enhance the economic well-being of the US economy. This web site includes the issue of corporate governance and this area includes links to the Roundtable's press releases and publications, including its Principles of Corporate Governance, as well as other useful subject categories with links including Business Ethics, SEC rules, the Sarbanes-Oxley Act, accounting and financial reform, executive compensation and more.

5.2.2. Corporate Directors Forum (www.directorsforum.com/). This association, whose membership comprises primarily corporate directors, aims to improve "board directorship by promoting high standards of professionalism". It offers members benefits such as peer networking, education and training, director mentoring and board recruitment resources. The corporate governance researcher will find some useful materials on this web site including freely available information on corporate governance guidelines and best practice, some freely available articles on corporate governance themes, and recommended links to corporate governance web sites.

5.2.3. National Association of Corporate Directors (NACD) (www.nacdonline.org/). This is a non-profit US-based membership organization for directors of corporations providing a wide range of membership services including continuing education for directors, publications, a corporate governance hotline and more. There is a section of the site titled "Governance Resources" which offers the corporate governance researcher many useful information resources, some of which are freely available. This includes Governance FAQs, full-text reports on topical areas such as Sarbanes Oxley Section 404, special corporate governance "issue centers" including full-text documents on topical themes such as governance reforms and regulations post-Enron, reducing director and officer liability exposure, family business governance and more.

5.2.4. Society of Corporate Secretaries and Governance Professionals (www. governanceprofessionals.org). This body is concerned with public disclosure under the securities laws and with other matters of corporate governance. Membership is primarily composed of corporate secretaries, assistant secretaries, business executives in governance and ethics, and those generally associated with compliance functions within corporations. The site features information resources and publications some of 
which are available to members only, and others that are freely available. Free information sources include: links to internet sites of interest, recent SEC releases and activities, and the society's newsletters.

\subsection{Australia}

5.3.1. Australian Institute of Company Directors (www.companydirectors.com.au/). This body (AICD) is Australia's membership institute for directors, similar to the NACD in the USA and the Institute of Corporate Directors in Canada (above). The AICD is dedicated to making a positive impact on the economy and society by promoting professional directorship and effective governance. The institute delivers a variety of educational offerings for Australian directors and also provides information, services and events consistent with this mission and desired by its members. The AICD also has a policy and advocacy function and publishes a number of position papers freely available to researchers.

\subsection{International}

5.4.1. International Corporate Governance Network (ICGN) (www.icgn.org). This is an international not-for-profit association based in the UK whose membership is open to anyone interested in the development of good corporate governance. ICGN organizes a prominent annual corporate governance conference to enable members to meet and exchange information. Information about this conference is available on the web site. The full-text of representations and statements from ICGN committees, which often make presentations to international organizations such as the OECD and the World Bank with the goal of influencing policy or proposals pertaining to corporate governance, are available and archived on the web site as far back as 1999. The News section of the site highlights key developments in corporate governance by profiling headlines from leading news sources including the Wall Street Journal, the Financial Times and resources such as CFO.com and more.

5.4.2. World Council for Corporate Governance (www.wcfcg.net/). This is an independent, not-for-profit international network which aims to share knowledge about best practices in corporate governance with company boards, policy makers, investors, fund managers, financial advisors, researchers, academics and other interested parties by creating active partnerships and fostering relationships between organizations committed to improving the quality of corporate governance worldwide. The Council organizes an annual conference on corporate governance and its web site features information about speakers, presentations and more. The Council also sponsors the Golden Peacock Global Award for Corporate Governance. This web site also offers some freely available full-text articles on a range of corporate governance themes, and a list of recommended web sites for corporate governance.

\section{Research centers, institutes and think-tanks}

In more recent years, as scholarship in corporate governance has emerged as a highly relevant and prominent area of business research, many universities have established corporate governance research centers or institutes. This institutionalization of corporate governance has occurred at a number of leading business schools, including the establishment of chairs or other endowments in the field. In addition to these academic research centers, there are a number of other important think-tanks and corporate 
governance research institutes, not affiliated with academic institutions, which have also established themselves as leading names in the field of corporate governance research. The corporate library serves as an important example of one such organization. Below is a selected list of research centers, institutes, and think-tanks, whose web sites could usefully be bookmarked by any corporate governance researcher.

\subsection{Academic}

6.1.1. Center for Corporate Governance at the Tuck School for Business (Dartmouth College) (http://mba.tuck.dartmouth.edu/ccg/). This research center supports, creates and publishes research on a wide range of corporate governance topics, including board effectiveness, corporate restructuring, global governance, governance investing and raising capital. The center's web site provides abstracts (and in some cases - the full-text) of articles outlining the center's views or research findings on corporate governance issues. The center also provides a list of recommended web sites in the following four areas: governance news, international agencies, shareholder activism, and research centers.

6.1.2 Center for Leadership and Corporate Governance (Wharton School) (http:// leadership.wharton.upenn.edu/governance/index.shtml). This web site features useful information for corporate governance research, including a substantial list of recommended web sites and information on corporate governance research at Wharton. The "Academic Readings" section of the site is impressive in that it offers recommended scholarly readings on a wide range of corporate governance topics, e.g. the board, CEOs, shareholders, etc., but visitors to this site will need to supplement their information obtained with other more current readings, as the most recent articles listed were published in 1999.

6.1.3. Corporate Governance Institute (San Diego University) (www-rohan.sdsu.edul dept/corpgov/news.html). This is a research and education center that is dedicated to the study and application of responsible corporate governance worldwide. The web site includes information about the Institute's researchers. The "Links" section is worth exploring as it offers a detailed annotated guide to the web sites of key organizations in the corporate governance field, as well as links and information on leading journals/newsletters in the field of corporate governance. While many of these journals require a subscription for viewing, the site will nonetheless prove valuable to any researcher developing familiarity with leading journal titles in the field.

6.1.4. John L. Weinberg Center for Corporate Governance (University of Delaware) (www.lerner.udel.edu/ccg/first.htm). This center is engaged in corporate governance research and education. The web site features information on courses and other education/training offered by the Center in corporate governance, the Center's press releases and more. Of particular interest or value to researchers of corporate governance is the section entitled "Research," which offers access to the Weinberg Center's working papers on corporate governance (the majority of which are available in full-text PDF format).

6.1.5. Millstein Center for Corporate Governance and Performance (at the Yale School of Management) (http://yccgp.som.yale.edu/). The center sponsors research and discussion designed to enrich and broaden the effectiveness of corporate governance. The web site features information on the mission of the center and on affiliated faculty and fellows. 
6.1.6. Program on Corporate Governance (at John M. Ohlin Center for Law, Economics and Business at Harvard) (www.law.harvard.edu/programs/olin_center/ corporate_governance/). This Program on Corporate Governance aims to promote research and scholarship in corporate governance. Areas of this web site which are especially worth exploring for those interested in corporate governance include: information about faculty research interests, links to working papers on corporate governance emanating from the program (many of which are available for free in full-text format), and the links to other recommended sites on corporate governance.

\subsection{Independent}

6.2.1. The Conference Board (US: www.conference-board.org/ Canada: www. conferenceboard.ca). The Conference Board of Canada and the Conference Board New York publish a substantial number of reports pertaining to the area of corporate governance. It is possible to register (for free) with the Conference Board e-Library when one visits the Conference Board of Canada web site. This e-Library is a searchable catalogue of all Conference Board research reports published since 1998. Quite a number of materials require payment of a fee, but a considerable number of the public policy documents are available free of charge, including some reports relating to corporate governance. Note that specific reports relating to the area of corporate governance can also be found linked on the Governance and Corporate Social Responsibility area of the Conference Board of Canada web site.

6.2.2. The Corporate Library (www.thecorporatelibrary.com). This independent organization is a leading provider of US corporate governance research information, including executive and director compensation information and analysis. While much of the information offered by the Corporate Library is fee-based, e.g. products for which it is well known, such as Board Analyst, and its high quality research reports and individual company reports, some valuable information on their web site is available free of charge. This includes a list of recommended corporate governance readings from Nell Minow, one of the founding members of the Corporate Library, and prominent researcher and scholar in the field of corporate governance. The site also includes a series of recommended corporate governance links, as well as a corporate governance blog with news relating to corporate governance, executive compensation, and regulatory topics. The archived research section of the site includes full-text documents pertaining to corporate governance best practice codes and case studies.

6.2.3. European Corporate Governance Institute (www.ecgiorg/). This is a non-profit research center network that brings together scholars and professionals in corporate governance. The primary goal of the institute is to undertake, commission, and disseminate research on corporate governance. This is a rich web site featuring links to the Institute's research working papers, as well as a searchable database of books written by its Fellows or Research Associates. The "Discussion and Debate" section of the site is also worth visiting, as it includes a brief overview of key corporate governance topics, e.g. executive remuneration, independent directors, shareholder activism, etc., in addition to links to publications (ECGI Working Papers and other academic papers and studies) on each area covered. The site also features links to the full text of corporate governance codes and guidelines for many countries across the globe, as well as offering links to recommended corporate governance web sites. 
6.2.4. Institutional Shareholder Services (www.issproxy.com). This firm conducts research on corporate governance and social responsibility. It provides fee-based proxy research and analysis, benchmarking products, as well as proxy voting services, and offers an online bookstore. A major part of its clientele are institutional investors, though it also provides services to corporations, law firms, foundations, academics, and more. While the vast majority of information on this site is fee-based, ISS is such a big name in the field of corporate governance that visiting their site is still recommended to gain an understanding of the activities of this organization. Indeed, there is some valuable information available free of charge including full-text documents relating to ISS' policy work (see ISS Policy Gateway) and the full-text of ISS reports, position papers, and working papers offered under the Governance Center.

\section{Corporate watchdog/advocacy sites: corporate governance}

It should serve as no surprise that when it comes to corporate governance themes, that corporate watchdog/advocacy sites are abundant. Indeed, searching the web reveals a plethora of sites from interest groups, advocacy groups and activists engaged in lobbying or raising public awareness of a range of corporate abuses or malfeasance, including corporate governance failures. The number and range of these sites have become especially apparent in the wake of the many corporate meltdowns in the early part of this century, which received high profile in the media.

While it is, of course, important to tread with caution when interacting with such web sites, as a specific agenda or self-interest is typically pursued, it would be a mistake to disregard such web sites out of hand. Indeed, to discount these web sites entirely would arguably leave the corporate governance researcher with a gap in his/her knowledge base in terms of an appreciation and understanding of corporate governance issues from all sides of the debate, on what are, after all, often controversial and highly topical issues. The authors found many sites, which fit with the description outlined above. In keeping with the article as a whole, however, they have been selective, narrowing it down to a choice of three recommended web sites, which are described below.

\subsection{AFL-CIO: Corporate Watch and Executive Paywatch}

The AFL-CIO, a voluntary federation of national and international unions, is based in the United States and makes available these two well-known corporate watchdog sites.

7.1.1 Corporate Watch (www.aflcio.org/corporatewatch/). This site aims to expose corporations in various ways, especially in terms of possible violation of workers' rights. Of particular note is the "Research Resources" section of the site, which highlights the main resources which union researchers use when investigating corporate practices and governance structures. While some of the sources listed clearly offer a distinct advocacy or interest group perspective, some include highly regarded names in news or business research.

7.1.2. Executive PayWatch (www.aflcio.org/corporatewatch/paywatch/). This resource (linked from the main Corporate Watch web site referenced above) includes information on trends in CEO pay, as well as on contested or controversial forms of executive compensation including "golden retirements", "top hat" plans, deferred compensation plans and more. Specific CEO pension case studies are provided as examples of excessive CEO retirement benefits. The site also features the Executive 
PayWatch database, which includes executive pay data for all S\&P Super 1500 corporations. This database can be searched by company name, industry and/or salary range. The site also explains how to find information on executive compensation in the USA using proxy filings.

\subsection{Corpwatch: Holding Corporations Accountable (www.corpwatch.org)}

This organization aims to investigate and expose abuses of corporations worldwide. The organization Corpwatch, where staff comprises mainly individuals with a background in journalism, was established nine years ago, as a project of the Tides Center, a nonprofit organization engaged in social change work. On their web site, CorpWatch claims to have "blown the whistle" on many corporations engaged in fraudulent or abusive behavior and states, for example, that they began to investigate Enron in 1998 three years before the company's collapse. A review of web site content quickly reveals a large amount of information including availability of full-text articles (current and archived) on a wide range of themes, which can be browsed within key headings such as Industries, Issues, and Research. Articles include such reputable sources as the New York Times, Bloomberg, and The Financial Times. Articles that are available on the site are also authored by CorpWatch staff. Note that many of the issues covered on the site, while clearly often taking a very critical stance on corporate activity, are highly relevant to the field of corporate governance, including executive compensation, worker rights, environmental responsibilities and abuses, accounting fraud, insider trading and other forms of corporate fraud. This site also offers guides on how to engage in company and industry research both in general terms and in terms of the social and environmental impact of a corporation or industry.

\section{Investor/shareholder services and information sites}

One of the most important, and increasingly most active, participants in the corporate governance field today are the shareholders, especially institutional investors, who hold a large number of shares in individual companies. These investors pay close attention to the corporate governance practices of the firms in which they hold shares. In fact, the role which institutional investors, such as pension funds, insurance funds, and mutual funds have come to play in the monitoring of corporate management and corporate governance, is quite widely recognized in the academic literature today (Solomon and Solomon, 2004). Firms with effective corporate governance performance are typically considered to be a lower investment risk.

To help major shareholders assess investment risk and monitor the corporate governance practices of the firms in which they invest, a large and growing business has emerged offered by professional service firms such as GovernanceMetrics International (GMI) and Institutional Shareholder Services (ISS). These types of firms engage in proxy research and analysis and offer proxy voting services and corporate governance ratings for firms. Since the services of such commercial entities are very largely fee-based, they are simply mentioned here, but not highlighted as a source of freely available web-based research information.

Shareholders themselves became more assertive especially in the 1980s. The founding of the Council for Institutional Investors (CII) in 1985 and other such organizations played a role in this development (National Association of Corporate Directors, 2006). Moreover, the use of voting rights by institutional investors has 
increased significantly in more recent years, particularly in respect of "majority votes" of directors and, increasingly, executive compensation matters, or "say over pay". Shareholders can also form representative groups and present resolutions to management - a more rare form of shareholder activism, more prevalent in the USA than elsewhere (Solomon and Solomon, 2004). Shareholder activism continues to be an important movement in corporate governance today. Major pension funds and other large institutional investors are indeed well-known for their research, principles, and practices in the area of corporate governance, e.g. CalPERS and TIAA-REF in the USA, Ontario Teachers Pension Plan in Canada and Hermes Pension Management Fund in the UK.

In light of the developments highlighted above, it is not surprising that a wide range of useful information (either free or fee-based) pertaining to corporate governance is made available on the web both by institutional shareholders themselves or organizations who represent them and by the professional service firms which have emerged to serve the corporate governance information needs of these major investors. Key sites of this nature, which offer significant information for free to users interested in corporate governance issues, are highlighted below:

\subsection{Canada}

8.1.1. Canadian Coalition of Good Governance (www.ccgg.ca/). Members include a wide range of institutional investors across Canada. This web site features a number of freely available information resources including best practice guidelines for investors (e.g., Canadian Coalition for Good Governance, 2006), proxy voting guidelines, general corporate governance guidelines compiled by the coalition, links to recommended web sites for corporate governance and more.

8.1.2. Ontario Teachers' Pension Plan: Corporate Governance (www.otpp.com/web/ website.nsf/web/cghome). A large pension fund, known for the leading role it has played in shareholder activism and in advancing corporate governance practices/principles in Canada, its web site features a section on corporate governance. This includes the fund's corporate governance policies and proxy voting guidelines, speeches delivered by leading individuals in the fund, research compiled or endorsed by the fund, as well as recommended corporate governance links.

\subsection{USA}

8.2.1. California Public Employees' Retirement System (CalPERS): Shareowner Forum (www.calpers-governance.org/). CalPERS is the largest public pension fund in the USA and has been a leader in the corporate governance movement, representing the interests of investors and shareholder for many years. This is the corporate governance site, which CalPERS makes publicly available. Most notably this site provides access to the "US corporate governance core principles and guidelines" (CaIPERS, 2006), an oft cited and highly regarded set of corporate governance principles and guidelines both within the USA and further afield. The site also features CalPERS global and international corporate governance principles, as well as US and international corporate governance proxy voting guidelines. This web site also includes information on securities litigation and class action links, as well as the full-text of CalPERS speeches and commentary in addition to their archived columns. 
8.2.2. Corporate Governance Network (www.corpgov.net/). The Corporate Governance Network at CorpGov.Net helps promote enhanced corporate governance practices by providing a network for the exchange of views and information about corporate governance. Founded in 1995 within the USA, this site aims to cater especially to the information needs of institutional investors and individual shareholders globally around issues of corporate governance. This site acts like a portal to many useful corporate governance resources including a Library which includes recommended lists of books and articles, full-text online format for some articles, papers and documents, and links to key publishers and journals in the field of corporate governance. The Links section of the site includes an impressive subject directory of recommended internet sites on a wide range of corporate governance topics.

8.2.3. Council of Institutional Investors (CII) (www.cii.org/). This is an organization whose members comprise large public, labor and corporate pension funds. It aims to encourage members to play an active role in protecting plan assets. The Library section of the site features a number of useful information resources including the Council's publications and correspondence. Of particular note within the Library section of the site is the Resource Center, which includes Council reports and communications on critical issues, e.g. Sarbanes Oxley Section 404 (internal control over financial reporting), and Council resources (proxy voting guidelines and background statements are available to members only, though a glossary of corporate governance terms is available to both members and non-members). The non-Council resources within the Resource Center, include a valuable subject directory of useful corporate governance internet-based resources, as well as links to academic studies on corporate governance.

\subsection{UK}

8.3.1. Hermes Pensions Management Limited (www.hermes.co.uk/). Hermes Pensions Management Ltd is a leading pension fund in the UK that is very active in the corporate governance movement. This web site offers the full-text of key corporate governance documents issued by Hermes, including the famous Hermes Principles.

\section{Conclusion}

Overall, there has been a rapid increase in the quantity and quality of corporate governance web sites over the last five years. The authors have attempted to distill categorically and critically the most important and robust web sites offering significant freely available information content. Readers of this article are thereby left with a good foundation for embarking on corporate governance research.

As the field of corporate governance continues to evolve, rapidly, there exists a likelihood that corporate governance information on the free web will become even more abundant and wide-ranging. Even today, the need to distill and evaluate this information is critical for effective research. Yet clearly as web-based information sources continue to grow and new corporate governance organizations and interests emerge, the development of objective, reliable, and independent methods of evaluating (or perhaps rating) the research value and output of corporate governance information on the free web will become more important and critical. Indeed, in other longer established disciplinary fields, there are examples of highly regarded, academically 
reliable subject gateways or portals, with evaluative commentary whereby researchers consult quality, freely-available, web-based information resources in their respective subject disciplines. Such gateways often emerge within academe and are hosted on the web sites of universities, although other forms of hosting or authorship may also apply.

In the field of corporate governance, there is a definite paucity of such subject gateways. The emergence of such comprehensive and robust "portals" or "meta-sites," featuring valid, reliable and trustworthy review processes for evaluating a variety of research dimensions (e.g., quality, quantity, timeliness, scope, relevance, etc.) would serve to advance the field of corporate governance greatly for end users, e.g. faculty, librarians and students within the academic setting, all of whom have aligned interests in discerning and acquiring the highest quality corporate governance information effectively and efficiently. This article may constitute one modest, though not insignificant, step in furthering this outcome.

\section{References}

CalPERS (2006), "US corporate governance core principles and guidelines", September 11, available at: www.calpers-governance.org/principles/domestic/us/page01.asp (accessed December 30, 2006).

Canadian Coalition for Good Governance (2006), "Best practices in shareholder communication", September, available at: www.ccgg.ca/media/files/guidelines_and_policies/BestPractices2006 FINAL.PDF (accessed December 30, 2006).

Carter, C.B. and Lorsch, J.W. (2004), Back to the Drawing Board: Designing Corporate Boards for a Complex World, Harvard Business School Press, Boston, MA.

Kim, J.J. (2005), "Free web link offers corporate-governance scores", Wall Street Journal, May 10, p. D2.

Leblanc, R.W. and Gillies, J.M. (2005), Inside the Boardroom: How Boards Really Work and the Coming Revolution in Corporate Governance, J. Wiley \& Sons Canada, Toronto.

National Association of Corporate Directors (2006), "National Association of Corporate Directors: corporate governance resources, education and information", available at: www. nacdonline.org/ (accessed December 30, 2006).

Solomon, J. and Solomon, A. (2004), Corporate Governance and Accountability, John Wiley, New York, NY.

Sonnenfeld, J.A. (2004), "Good governance and the misleading myths of bad metrics", The Academy of Management Executive, Vol. 18 No. 1, pp. 108-13. 